\title{
BERPIKIR DALAM PENDIDIKAN: (Suatu Tinjauan Filsafat Tentang Pendidikan Untuk Berpikir Kritis)
}

\author{
Oleh: Muhammad Haviz*
}

\begin{abstract}
This article is a study about how to think in education. Thinking in education should be integrated in process of learning at colleges. In philosophy, thinking in education is one of means of education for critical thinking. Effectively, thinking in education used to study some problems in education. Thinking in education is metacognition. As a part metacognition, critical thinking applied in college will produced a high quality outcomes. In other words, learning process in colleges wich involved lecturers and students interaction if and appropriate process of building the critical thinking pattern. This pattern will effective if the process is formed integratedly the college policies. Since it will affect to all of educational aspect. It is hopped the result of critical thinking in education will be able to help people in drawing a conclusion as well as applying it in their real life.
\end{abstract}

Kata kunci: thinking, critical thinking, effective, education

\section{PENDAHULUAN}

$\mathrm{B}$ anyak pendapat menjelaskan bahwa seseorang sudah terlahir sebagai seorang yang pintar atau bodoh, karena keduanya tercipta tergantung kepada suatu kemampuan yang disebut dengan intelegensi. Tetapi, pernyataan tersebut kurang tepat dan cenderung tidak benar. Karena berdasarkan teori perkembangan kognitif Piagets, intelegensi seseorang ditentukan oleh bagaimana dia mengasah kemampuan dan kematangan otaknya (Wadsworth, 1979). Berpikir merupakan salah satu bagian atau menjadi objek penting yang harus dimiliki oleh setiap unsur pendidikan tinggi (Ricketts, 2004).

Apakah berpikir itu? Apa manfaatnya? Pertanyaan ini sekilas terdengar aneh dan tidak selayaknya dipertanyakan. Terlebih lagi, jika dipertanyakan pada "unsur pendidikan tinggi". Karena unsur pendidikan tinggi sudah sangat mengetahui dan memahami tentang apa dan bagaimana berpikir. Tetapi, apakah pengetahuan dan pemahaman yang tinggi yang telah dimiliki oleh unsur pendidikan tinggi tersebut telah memberikan hasil yang baik? Hasil yang baik dalam pendidikan, tentunya mengacu kepada tujuan pendidikan nasional. Dalam UU Nomor 2 Tahun 1989, tujuan pendidikan nasional adalah mencerdaskan kehidupan bangsa dan mengembangkan manusia Indonesia seutuhnya, yaitu manusia yang beriman dan bertakwa terhadap Tuhan Yang Maha Esa dan berbudi pekerti luhur, memiliki pengetahuan dan keterampilan, kesehatan jasmani dan rohani, kepribadian yang mantap dan mandiri serta rasa tanggung jawab kemasyarakatan dan kebangsaan.

Sekarang, banyak peristiwa yang menggambarkan tidak tercapai tujuan

* Penulis adalah Staf Pengajar Pendidikan Biologi pada STAIN Batusangkar 
pendidikan nasional. Jika dilihat dalam proses belajar, banyak sikap unsur pendidikan tidak menggambarkan pencapai tujuan tersebut. Penulis secara khusus menyoroti sering terjadi tawuran antar mahasiswa di beberapa perguruan tinggi di Indonesia. Banyak sekali jawaban yang bisa diberikan. Salah satunya adalah kurang mampunya mahasiswa bersikap dan berbudaya ilmiah. Menurut Jama (2008) ketidakmampuan mahasiswa untuk berbicara, menulis dan bersikap ilmiah, karena sistem tidak menciptakan kondisi mahasiswa untuk berpikir kritis. Selanjutnya, Jama (2008) menjelaskan tidak terciptanya budaya ilmiah karena kurang mampunya mahasiswa untuk beretorika. Karena, kemampuan beretorika akan lahir, jika mahasiswa bisa berpikir kritis (Haviz, 2003; Haviz et.al 2007). Karena, memiliki kemampuan berpikir merupakan salah satu tujuan dalam pendidikan (Burton et.al, 1960).

Berpikir kritis ini bisa diaplikasikan dalam proses belajar di kelas. Hasil penelitian di Western Cap Education Departement tahun 1998-2000 menunjukkan bahwa kemampuan kognitif outcomes berhubungan erat dengan kemampuan berpikir kritis dan efektif. Temuan penelitian ini juga memperlihatkan bahwa mahasiswa yang terlibat dan ikut melaksanakan kebijakan, akan mampu bersikap ilmiah jika didukung dengan semua perangkat kebijakan dan sistem di departemen tersebut (Abel et $a l$, 2006). Hasil penelitian lain yang menggambarkan pendidikan secara luas mampu meningkatkan kemampuan berpikir adalah penggunaan problem solving dalam mata kuliah perkembangan hewan (Lufri, 2004), berpikir kritis dalam pendidikan biologi (Pettersen, 1992), berpikir kritis dalam membangun kepemimpinan (Ricketts, 2004), metodemetode penentuan kemampuan berpikir kritis (Stein et.al, 2003), peningkatan kemampuan berpikir di dalam kelas (Irfaner, 2006), keterpaduan sistem berpikir di dalam pendidikan teknologi sistem informasi (Vo et. al, 2006), pengembangan kemampuan berpikir dalam pendidikan kejuruan (Levin dan Lieberman, 2008; Al-Jayyousi, 1999).

Berpikir dalam pendidikan bisa dibedakan atas berpikir kritis, berpikir kreatif, berpikir peduli, berpikir efektif (Lipman, 2003). Artikel ini bertujuan untuk membahas bagaimana berpikir dalam pendidikan. Secara khusus, tulisan ini juga menelaah berpikir kritis dalam pendidikan.

\section{TINJAUAN FILOSOFIS BERPIKIR KRITIS, APAKAH BERPIKIR KRITIS?}

Maksud dari berpikir kritis adalah untuk mencari kesimpulan yang benar dengan pemecahan masalah, menjawab keraguan dan mampu membedakan antara doktrin dengan kebijakan. Bisakah kita melakukannya? Mengertikah kita kapan kita berhenti dan kapan kita berpikir? Apa yang harus dilakukan?

Penulis mengutip pendapat beberapa ahli filsafat tentang berpikir kritis. Menurut Deweys (1938, dalam Akshir, 2007) berpikir adalah suatu kegiatan yang aktif, tepat dan hati-hati dalam mempercayai sesuatu atau informasi yang datang dari luar sehingga tidak salah dalam merefleksikan pemikiran tersebut ketika membuat suatu kesimpulan. Selanjutnya, Menurut Deweys (1938, dalam Akshir, 2007) refleksi pemikiran akan membedakan suatu tindakan dalam mencari dan menemukan materi untuk menjawab keraguan, kebingungan dan kesulitan mental dalam berpikir.

Menurut Ennis (1985) berpikir kritis merupakan alasan untuk merefleksikan pemikiran yang terpusat pada apa yang dipercaya dan apa yang dilakukan. Facione (1984) menjelaskan berpikir 
kritis berhubungan dengan perkembangan dan evaluasi dari seseorang ketika berargumentasi. Selanjutnya, Lipman (1988) menjelaskan, berargumen adalah bagian dari berpikir, dan dilengkapi dengan tanggungjawab yang tinggi ketika menyatakan sesuatu, karena (1) apa yang disampaikan merupakan realita, (2) merupakan koreksi dari diri sendiri dan (3) pernyataan tersebut sesuai dengan apa yang dibicarakan.

Siegel (1991) menambahkan, untuk meningkatkan kemampuan berpikir, seorang pemikir kritis harus mempunyai semangat berpikir kritis, yang bisa dilihat dari kemampuan alami dan perasaan untuk berpikir kritis. Penjelasan singkat Paul (1995) tentang berpikir adalah berpikirlah tentang pemikiranmu karena ketika kamu berpikir akan membuat pemikiranmu menjadi lebih baik.

Konsep McPecks (1990) tentang berpikir kritis berbeda dengan dengan Ennis dan Paul, dia menyatakan bahwa berpikir kritis merupakan skill yang tidak bisa dijeneralkan, karena berpikir kritis tidak bisa diisolasi secara lengkap. Esensi dari berpikir kritis adalah perasaan dan skill untuk meningkatkan kemampuan dalam beraktifitas yang cenderung membuat seseorang untuk menjadi skeptis. McPecks menganggap tidak mungkin ada penyelesaian ketika berpikir tentang sesuatu karena akan selalu ada permasalahan yang muncul dan bisa dipertanyakan.

Menurut Burton et.al (1960) dalam berpikir seseorang harus menjalani; pertama, proses yang mampu meningkatkan keraguan dalam pemikiran dan kedua mengetahui kesulitan dalam keraguan tersebut. Ketiga menguji keraguan tersebut dengan memberikan fakta, merancang hipotesis dan mencari fakta-fakta baru dengan melakukan observasi, keempat mengkritisi fakta tersebut, kemudian menginterpretasikannya, dan kelima membuat kesimpulan berdasarkan teori, temuan dan realita yang ada.

Jika ditinjau dari aspek psikologis, konsep berpikir kritis merupkan bagian yang tidak bisa dipisahkan dari filsafat. Karena berpikir dalam psikologi menjadi aspek aksiologis dari filsafat. Teori berpikir kritis berdasarkan psikologis dikeluarkan dan dibangun dari dimensi kognitif. Bartlett (1985) mendefenisikan berpikir dari aspek psikologis, yaitu merupakan pelebaran dari fakta. Siegel (1984) memandang berpikir kritis sebagai proses aktif yang berkaitan dengan mental seseorang saat berkomunikasi dengan orang lain, terutama saat menjalani proses induksi, deduksi, mengemukan alasan, memberikan persamaan, mengelompokkan dan mendefenisikan sesuatu.

Burton (1960) melihat berpikir diawali dengan melihat masalah yang mempunyai rentangan, dan rentangan masalah yang dipikirkan diawali dari mudah hingga sulit. Beberapa pemikiran Burton (1960) tentang filosofis berpikir adalah :

1. Berpikir selalu hilang dan peduli. Datang dan perginya informasi merupakan suatu hal yang biasa dalam berpikir. Kehilangan informasi sebelumnya bisa saja terjadi karena peduli dengan informasi baru yang lebih efektif dan dalam rangka menemukan kepastian. Karena perbedaan tindakan atau anggapan terhadap informasi yang melibatkan pemikiran akan melahirkan kesimpulan yang lebih baik (Dewey, 1944).

Menurut penulis sebuah Ilustrasi singkat yang sesuai dengan pernyataan di atas adalah kisah pencarian Allah SWT Sang Pencipta Alam Semesta oleh nabi Ibrahim AS. Awalnya, matahari yang menerangi bumi di siang hari dianggap sebagai Sang Pencipta. Tetapi, munculnya bulan dan bintang di saat malam mementahkan kesimpulan yang telah dibuat 
oleh Ibrahim sebelumnya. Sehingga, Nabi Ibrahim menemukan suatu kesimpulan bahwa Yang Menciptakan alam semesta beserta isinya yang diyakininya sebagai Tuhan yang sangat dekat dan paling dekat dengan dirinya. Dan ketika hamba-hamba-Ku bertanya kepadamu tentang Aku, bahwasanya Aku dekat....... (Q.S, 2 : 186).

2. Mengingat adalah berpikir. Seseorang yang mengingat sesuatu dalam pemikirannya dianggap orang tersebut sudah berpikir.

3. Menggambarkan/memimpikan adalah berpikir. Menggambarkan (imaging) dan memimpikan (dreaming) adalah bagian dari berpikir. Seorang yang berpikir seperti bermimpi. Karena sesuatu yang akan dibicarakan telah melewati proses penggambaran atau imaging dalam pemikiran. Saat bersikap, telah melewati proses mimpi atau dreaming dalam pemikirannya. Dengan proses imaging dan dreaming sebagai bagian dari berpikir, seseorang mampu melakukan dan meraih sesuatu yang tidak biasa.

Hirata (2005), dalam bukunya yang berjudul "Laskar Pelangi" menceritakan perjuangan 10 orang anak melayu kurang mampu (miskin) asal Belitong saat bersekolah. Dengan segala keterbatasan sarana, prasarana serta hambatan yang muncul, mereka tetap dengan penuh semangat pergi ke sekolah. Secara kolektif, hasilnya terlihat saat diadakan lomba karnaval 17 Agustusan dan lomba cerdas cermat. Para laskar pelangi mampu mengalahkan siswa dari SD lain yang lebih berkualitas. Selanjutnya, Ikal dan Arai (dua bocah laskar pelangi) ternyata mampu bersekolah ke Paris, menjelajahi Eropa dan bahkan sampai ke Afrika (Hirata, 2006). Menurut penulis, saat kecil, mereka telah me- lakukan proses yang dinamakan berpikir. Secara individual, kedua anak ini juga telah mengalahkan teman dalam kelompok mereka. Dalam buku tersebut diceritakan bahwa Ikal dan Arai kecil telah memimpikan untuk bisa bersekolah ke suatu tempat yang paling indah di dunia yaitu ke Sorborne University Paris-Perancis. Bersekolah di Perancis selalu tergambar dalam pemikiran mereka. Proses imaging dan dreaming memicu semangat mereka untuk mewujudkan mimpi-mimpi mereka menjadi kenyataan.

4. Percaya adalah berpikir. Saat seseorang telah mempercayai sesuatu, maka dia telah melakukan proses yang dinamakan berpikir. Colombus meyakini dan percaya bahwa dunia bisa diarungi. Selanjutnya, pada tahun 1980-1990, Habibie dengan kemampuannya dalam mendesain aerodinamis pesawat terbang, mampu memimpin PT. Dirgantara Indonesia memproduksi sejumlah jenis pesawat terbang sendiri, seperti CN-235. Menurut Penulis, Columbus dan Habibie telah melakukan proses yang dinamakan berpikir. Columbus meyakini dan mempercayai bahwa dunia bisa diarungi, dan Habibie meyakini serta mempercayai bahwa dengan ilmu disain aerodinamis yang dimilikinya, suatu saat Indonesia mampu memproduksi pesawat sendiri. Mereka mampu melakukannya setelah melewati proses mendengar, mengamati dan mempercayai apa yang dibicarakan orang.

Banyak sekali defenisi, pernyataan serta ilustrasi berpikir dalam pendidikan. Pengertian terbaik berpikir dalam filsafat adalah bagaimana berpikir bermanfaat dalam pendidikan. 


\section{IMPLIKASI BERPIKIR DALAM PENDIDIKAN}

Berpikir diperlukan dan merupakan bagian dari pendidikan. Seyogyanya hal ini dipogramkan dalam suatu kebijakan. Karena, program ini sangat mempengaruhi kualitas lulusan suatu perguruan tinggi. Menurut Baillin et al. (1999) konsep berpikir kritis dalam pendidikan harus terintegrasi dengan baik, jika outcomes dari perguruan tinggi tersebut ingin dibekali dengan kemampuan berpikir. Konsep pemikiran Bailin ini menggambarkan mustahil jika produk suatu perguruan tinggi yang mampu berpikir lahir tanpa adanya proses. Artinya, seorang dosen sebagai bagian dari penyelenggara pendidikan harus terlibat aktif menjadikan mahasiswanya berpikir. Dan mahasiswa juga harus ikut serta dan mampu mengaplikasikannya dalam menyelesaikan setiap masalah yang dihadapinya saat belajar.

Implikasi berpikir dalam pendidikan, memiliki alur dan proses yang cukup jelas dan memahami alur dan proses tersebut tidaklah sulit. Tetapi, bagi seorang dosen menjadi tugas yang berat tetapi mulia untuk mengajarkannya. Menurut Russel (1956, dalam Burton et al, 1960) alur berpikir yang bisa dipahami oleh mahasiswa dan dosen diawali dengan adanya stimulus, kemudian diinterpretasikan, dilanjutkan dengan proses dan diakhiri dengan lahirnya kesimpulan. Skema berpikir dalam pendidikan terlihat di bawah ini:

Emosi, kebutuhan dan

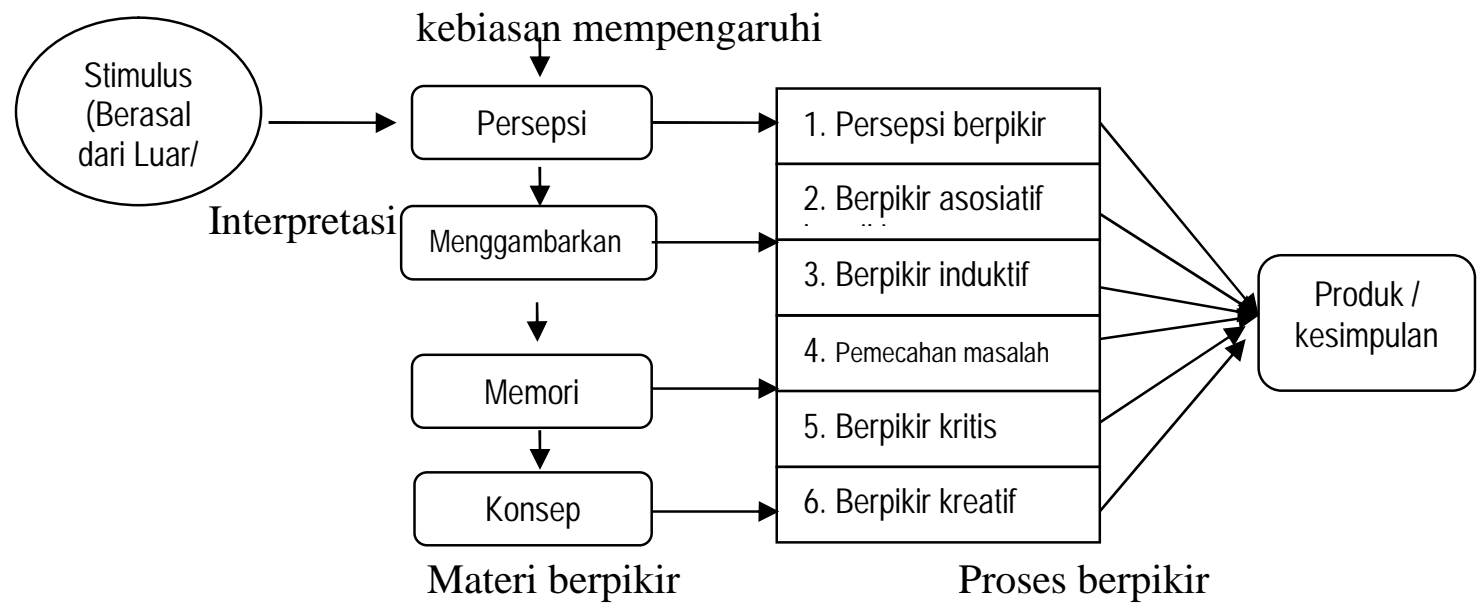

Gambar 1. Alur implikasi berpikir dalam pendidikan (Dimodifikasi dari Burton et. al, 1960; Kantowitz \& Roediger, 1984)

\section{KEMAMPUAN METAKOGNITIF SEBAGAI BAGIAN BERPIKIR DALAM PENDIDIKAN}

Berpikir dalam pendidikan berhubungan erat dengan kemampuan metakognitif. Sejatinya, seorang dosen atau pendidik harus menjadi seseorang yang mampu berpikir dengan baik atau memiliki kemampuan berpikir dengan kritis dengan baik, sehingga juga bisa diajarkan dengan baik kepada mahasiswa atau peserta didiknya. Pertanyaan yang muncul adalah mengapa kemampuan 
metakognitif ini penting untuk diajarkan? Bagaimana dia diajarkan? Bagaimana penentuan atau evaluasinya? Dan apa yang harus dilakukan oleh seorang pemikir yang baik? Penulis mengajukan beberapa pertanyaan lain yang menelaah jawaban pertanyaan sebelumnya. Pertanyaan dan jawabannya ditampilkan berdasarkan pemikiran Piaget's yang ditulis oleh Burton et. al (1960), Abel et. al (2006), (Forman, 1968) dan ahli pendidikan lainnya.

\section{Apakah pendidikan kognitif itu?}

Berdasar teori perkembangan kognitif Piaget's, pendidikan kognitif adalah pendidikan yang mengajarkan kepada pelajar pengetahuan baru dan juga bagaimana berpikir dan belajar (Wadsworth, 1979). Pendidik yang beraliran kognitif lebih banyak berbicara tentang pembelajaran untuk mengembangkan kognitif peserta didik. Kemampuan kognitif merupakan istilah yang sering diberikan kepada semua proses yang berhubungan dengan berpikir. Banyak orang menggunakan tema kognitif hanya pada proses berpikir rasional saja, tapi ada juga yang mengaitkannya dengan proses berpikir kreatif dan imajinatif.

Banyak alasan yang bisa digunakan untuk menjelaskan bagaimana "format" berpikir. Secara gamblang bisa dijelaskan bahwa pendidikan kognitif fokus pada proses yang membangun kemampuan untuk berpikir secara kritis dan analitis. Berpikir kognitif merupakan kegiatan yang bersifat holistik dan bukan parsial. Berpikir efektif dalam kognitif harus menggunakan alasan yang rasional.

Pendidikan kognitif berdasarkan teori konstruktivisme Piaget's (Forman, 1968) merupakan pendekatan menggunakan model proses informasi sebagai jalan untuk menjelaskan berpikir saat belajar. Model ini menunjukkan bahwa berpikir saat belajar merupakan suatu aksi yang membangun kognitif seseorang. Aksi tersebut dibedakan menjadi input, elaboration dan output.

Pada fase input, mahasiswa/pelajar akan menerima informasi. Mereka akan "meregister" dan "membuat tanda" dari apa yang dibaca atau dibicarakan. Akhirnya mahasiswa/pelajar akan mengorganisasikan informasi tersebut di dalam pemikiran mereka. Input berupa informasi tersebut bisa berupa suara, kalimat, gambar, ide, rasa ataupun berupa tugastugas yang diberikan dosen.

Pada fase elaboration, mahasiswa/pelajar akan mengembangkan organisasi informasi tersebut. Mereka akan mengetahui hubungan antara informasi yang diterima dengan konsep yang ada. Tahap ini cukup sulit dilakukan, karena akan terjadi benturan antara input informasi dengan konsep yang telah dipahami sebelumnya. Tetapi, kualitas output akan sangat ditentukan melalui tahap ini.

Pada fase output, mahasiswa/ pelajar harus mampu menseleksi apa yang mereka ketahui untuk membuat suatu pemecahan masalah atau saat menjawab sebuah pertanyaan. Mahasiswa/ pelajar harus mampu menunjukkan atau membuat kesimpulan dari pengetahuan sudah yang dipunyai. Kesimpulan tersebut bisa berupa kata-kata, pernyataan atau dalam bentuk esay. Kemudian, mereka harus bisa menjelaskan, mendiskusikan, mendemonstrasikan dan melakukan tindakan.

Setiap fase mengandung makna bahwa langkah penting dalam proses kognitf atau alat berpikir akan membuat penyerapan informasi lebih efektif. Karena bagian ini ditemukan proses dasar yang sangat terkait dengan fungsi otak. Misalnya, bagaimana langkah-langkah untuk membangun dan menemukan pengetahuan baru (inkuiri). Model ini akan sangat membantu proses pembelajaran dan evaluasi kognitif pelajar. Proses pembelajaran harus melalui fase 
input (bagaimana menerima informasi), elaboration (bagaimana mengorganisir/ mengidentifikasi informasi dan output (mengekspresikan apa yang diketahui). Model ini juga bisa digunakan untuk mengidentifikasi kesulitan-kesulitan dalam proses pembelajaran yang tertuang dalam berpikir efektif. Lebih lanjut, model ini disebut dengan Metacognition (Abel et.al, 2006).

\section{Mengapa penting untuk diajarkan?}

Pemikir yang baik harus selalu menjadi yang terdepan dalam menciptakan pembelajaran yang lebih baik. Pemikir yang baik juga harus memiliki tanggungjawab dalam komunitas pendidikan. Pemikir kritis harus mampu menggambarkan dan mengimplementasikan berpikir baik dalam rangka ikut serta menyelesaikan masalah yang ditemukan dalam kelompoknya. Lebih lanjut, berpikir kritis akan efektif jika digunakan untuk membantu penyelesaian masalah dan menciptakan demokrasi dalam pendidikan.

Menurut penulis, ada beberapa manfaat dari berpikir dalam pendidikan : (1) membuat seseorang lebih mampu menghadapi dan meraih tujuannya dalam belajar, (2) mengantisipasi kesulitan atau masalah yang muncul dalam belajar, (3) meningkatakan kemampuan memahami dan memaknai materi dalam belajar dan (4) berkontribusi dalam menjaga hubungan sosial. Pendapat sama dikemukan oleh Burton et. al (1960) berpikir akan membangun sikap yang sistemik dalam kehidupan sehari-hari dalam rangka meraih tujuan dalam belajar.

\section{Apakah medianya?}

Media akan membawa dan menghubungkan mahasiswa/pelajar dengan pengetahuan baru, sehingga membuat belajar lebih mudah dan sesuai dengan apa yang diharapkan. Para ahli kognitif selalu mengacu dan menggunakan pen- dekatan kognitif yang berfungsi sebagai media untuk membantu menumbuhkan kemampuan dan sikap berpikir dalam diri pelajarnya.

Manusia menggunakan dua cara belajar dalam fase perkembangannya, yaitu pertama; belajar secara bebas (belajar dengan cara mencoba dan salah/trial and error) dan kedua; belajar dengan menggunakan media. Belajar menggunakan media bisa dilakukan dengan membaca buku, kaset, video atau yang lainnya. Bahkan bisa dari orang yang berfungsi sebagai mediator, misalnya belajar dari guru/dosen. Belajar dengan dosen/guru yang berfungsi sebagai mediator, akan lebih membantu mahasiswa/pelajar untuk menginterpretasikan pemahaman tentang konsep yang sebenarnya. Saat yang sama, mediator juga bisa mengarahkan mahasiswa/pelajar untuk bisa belajar berpikir baik. Sehingga para mahasiswa/pelajar mengetahui bahwa pengalaman penting dalam belajar. Pengalaman yang dimiliki oleh pelajar/mahasiswa akan meningkatkan ke-mampuan berpikir mereka.

Skema di bawah ini memperlihatkan hubungan antar mahasiswa/ pelajar dan dosen/guru sebagai mediator dalam proses belajar dan berpikir.

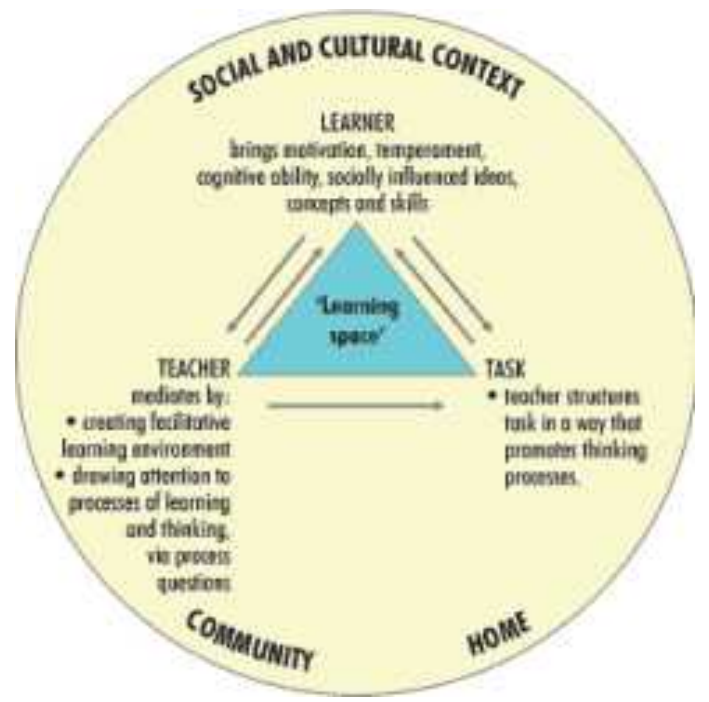

Gambar 2. Hubungan antar pelajar dan guru sebagai mediator dalam 
proses belajar dan berpikir

(Abel et. al, 2006)

\section{PEMBELAJARAN MENGGUNA- KAN MEDIA BERPIKIR}

Pembelajaran menggunakan media adalah proses pembelajaran yang memberikan kesempatan kepada pelajar agar belajar berdasarkan pengalaman. Proses ini dilakukan dengan membuat suasana dalam kelas bisa berpikir. Dalam pendidikan kognitif diharapkan pendidik mampu berfungsi sebagai mediator untuk mengembangkan sikap berpikir bagi peserta didiknya Abel et. al (2006).

Abel et. al (2006) menjelaskan ada tiga kriteria yang harus dimiliki oleh seorang pendidik untuk bisa menjadi seorang mediator dalam pembelajaran, yaitu intentinality dan reciprocitiy (tujuan dan hubungan timbal balik), meaning (pemahaman) dan trans-cendence (transenden). Seorang pendidik harus mampu mengajarkan bagaimana memecahkan masalah, bagaimana bertutur kata dengan baik saat berada dalam suatu masalah atau bagaimana mengatur pikiran dalam menyelesaikan masalah tersebut.

Saat proses belajar berlangsung, pengajar yang berfungsi sebagai mediator harus intensif menanyakan pertanyaan berikut: (1). How do you know that? / (Apa yang anda ketahui tentang masalah tersebut?), (2) What made you think that this might be the case? (Bagaimana pendapat anda tentang masalah ini?), (3) Could be wrong about this? (Bisakah ini disalahkan?), (4) At what stage were you sure this was the right answer? (Pada bagian atau tahapan apa yang membuat anda yakin bahwa jawaban tersebut benar?), (5) What reasons made you think that? (Apa alasan yang membuat anda berpikir tentang itu?) (6) What kind of classification do you think could work here? (Atas dasar apa anda berpikir untuk mengelompokkan masalah tersebut?) (7) What did you use as criteria for identifying? (Kriteria apa yang anda gunakan untuk mengidentifikasi masalah tersebut?), (8) What could be a better way to plan what you do? (Bagaimana jalan terbaik untuk merancang apa yang anda inginkan?) dan (9) What would be away to do this differently? (Apa yang harus dilakukan untuk membuatnya berbeda dengan yang lainnya?)

\section{Apa yang harus dilakukan oleh pemikir yang baik?}

Seseorang pemikir yang baik dan terlibat dalam dunia pendidikan harus bisa:

1. Mengidentifikasi dan mencari solusi masalah (identify and solve problems) dan mampu membuat keputusan berdasarkan pemikiran yang kritis dan kreatif.

2. Berkerja secara efektif dengan orang lain dalam sebuah tim kerja, organisasi dan komunitas bersama.

3. Mampu mengorganisir dan memanajemen aktivitas mereka secara bertanggung jawab dan efektif.

4. Mengkoleksi, menganalisis, mengorganisasi dan mengevaluasi setiap informasi secara kritis.

5. Berkomunikasi efektif dengan menggunakan metode visual dan simbol bahasa yang bervariasi.

6. Menggunakan sains dan teknologi yang efektif dan kritis, untuk menunjukkan tanggungjawab dan "lingkungan" yang sehat.

7. Mendemonstrasikan pemahaman kata yang disusun dalam suatu sistem yang berorientasi kepada pemecahan masalah dan tidak mengisolasi diri.

8. Mengeksplorasi strategi dalam pembelajaran yang lebihn efektif.

9. Berpartisipasi dalam komunitas lokal, nasional dan internasional. 
10. Berbudaya dan berestetika kritis dan efektif dalam sosial.

11. Mengembangkan karir dalam pendidikan.

12. Mengembangkan jiwa enterpreneurships.

\section{KESIMPULAN}

Berpikir dalam pendidikan, secara filosofis bisa diimplementasikan ke dalam bentuk berpikir kritis. Pengamatan yang dilakukan secara kritis terhadap setiap masalah, merupakan bentuk sikap dan tanggapan yang efektif dalam pendidikan. Tindakan ini harus dilakukan oleh setiap unsur pendidikan, sehingga tujuan pendidikan bisa tercapai. Khususnya, untuk membantu seseorang untuk berpikir secara baik dalam membuat suatu kesimpulan. Karena, penerapan sebuah kesimpulan yang lahir dari pe-

\section{DAFTAR RUJUKAN}

Abel et al. 2006. Better thinking-better learning; Introduction to Better Thinking. Western Cape Education Departement, South Africa. In http://www.wcape.school.za/curric ulum. (Diakses 1 Nopember 2008).

Akshir MAK. 2007. Critical thinking a family resemblance in conceptions. Journal of Education and Human Development Vol 1(2): 11-23.

Al-Jayyousi O. 1999. Introduction of lateral thinking to civil and environmental engineering education. Int. J. Engng Ed. Vol. 15, No. 3: 199-205.

Al-Quran dan Terjemahannya. Departemen Agama RI. PT. Karya Toha Putra. Semarang. mikiran tersebut, sangat menentukan keberhasilan dalam mengatasi masalah pendidikan yang ditemukan.

Berpikir merupakan bagian dari pendidikan metakognitif. Sebagai bagian dari pendidikan metakognitif, berpikir kritis akan menghasilkan outcomes yang lebih berkualitas. Secara sederhana, proses belajar yang melibatkan dosen dan mahasiswa di perguruan tinggi merupakan salah satu proses yang tepat untuk membentuk pola berpikir kritis.

Berpikir kritis akan efektif jika melewati proses yang terintegrasi dalam suatu kebijakan, karena kebijakan tersebut akan mempengaruhi setiap unsur pendidikan. Harapannya, pendidikan mampu membantu seseorang untuk berpikir tepat dalam membuat suatu kesimpulan dan mampu mengaplikasikannya dalam kehidupan. Sekarang, mampukah kita menyikapinya dengan bijak?

Baillin S, Coombs JR \& Daniels LB. 1999. Conceptualizing critical thinking. Journal of Curriculum Studies, 31: 285-302.

Bartlett FC. 1985. Thinking: an experimental and social study. London: Allen \& Unwin.

Burton HW, Kimbal RB \& Wing RL. 1960. Education for effective thinking. New York: Appleton Century Crofts, Inc.

Dewey J. 1944. Democracy and education. New York: The Free Press A Division of Macmillan Publish Co, Inc.

Ennis RH. 1985. A logical basis for measuring critical thinking skills. 
Educational Leadership (43): 4448.

Facione PA. 1984. Toward a theory of critical thinking. Liberal Education, 70: 253-261.

Forman GE. 1968. Constructivism piagets, in theory of learning-a comparative approach. Itaca Illinois: FE Peacock Publishers, Inc.

Haviz, M. 2003. Sukses sebagai mahasiswa plus aktifis. Makalah Seminar Akademik. Biologi FMIPA Universitas Negeri Padang, 23 April 2003.

Haviz M, Yuzarion, Faulina N, Febrianti D \& Agusni. 2007. Kiat-kiat sukses menjadi mahasiswa dan aktifis kampus. Makalah Pengabdian kepada Masyarakat. Tanggal 1 Mei 2007. STKIP PGRI Sumbar.

Hirata A. 2005. Laskar pelangi. Edisi pertama. Penerbit Bentang. Yogyakarta.

Hirata A. 2006. Sang pemimpi. Edisi pertama. Penerbit Bentang. Yogyakarta.

Irfaner I. 2006. Enhancing thinking skills in the classroom. Humanity \& Social Sciences Journal 1 (1): 2836.

Jama J. 2008. Pentingnya budaya Ilmiah di UNP. Artikel Surat Kabar Kampus Ganto. Edisi No. 146/Th XIX/Agustus-September 2008.

Kantowitz BH \& Roediger HL. 1984. Memory and information processing. in Theory of Learninga comparative approach. Itasca Illinois: FE Peacock Publishers, Inc.

Levin I \& Lieberman E. 2008. Developing Analytical and Synthetic Thinking in Technology Education. in http/www/edu/ thinking tech/(diakses 1 Nopember 2008).

Lipman M. 1988. Critical thinking-what can it be?. Educational Leadership, 45: 38-43.

Lufri. 2003. Pembelajaran berbasis problem solving yang diintervensi dengan peta konsep dan pengaruhnya terhadap berpikir kritis mahasiswa dalam mata kuliah perkembangan hewan. Jurnal Penelitian Kependidikan Vol 13. No. 2 Des: 212-228.

McPecks J. 1990. Teaching critical thinking. Great Britain: Routledge.

Paul R. 1995. Critical thinking: how to prepare students for a rapidly changing world. California: Foundational for Critical Thinking.

Pettersen S. 1992. Critical thinking in norwegian upper secondary biology education: The Cases of Complementary-Alternative-

Medicine and Health Claims in the Media. Faculty of Vocational Teacher Education, Akershus University College, Lillestrom, Norway.

Ricketts JC. 2004. Critical thinking skills of FFA leaders. Journal of Southern Agricultural Education Research. Vol. 54 (1): 7-20.

Siegel H. 1991. The generalizability of critical thinking. Educational Philosophy and Theory, 23 (1): 1830.

Sigel IE. 1984. A constructivist perspective for teaching thinking. Educational Leaderships, 42(3): 18-21.

Stein BS, Haynes AF and Unterstein J. 2003. Assesing critical thinking skills. Paper presented at SACS/COC Annual Meeting, 
Nashville Tennessee Dec 6 - 9 2003.

Wadsworth BJ. 1979. Piaget's theory of cognitive development, an introduction for students of psychology and education. Second edition. New York: Longman Inc.

Vo HV, Chae B and Olson DL. 2006. Integrating systems thinking into IS education. Syst. Res. 23: 107121. 